\title{
MANZANO, JUAN FRANCISCO. A AUTOBIOGRAFIA DO POETA-ESCRAVO. ORGANIZAÇÃO E TRADUÇÃO DE ALEX CASTRO. SÃO PAULO: HEDRA, 2015.
}

Gustavo de Oliveira Bicalho*

Quando olho para o espaco percorrido Desde meu berço, e todo meu progresso, Estremeço e saúdo meu sucesso Mais por terror que por amor movido.

MANZANO. A autobiografia do poeta-escravo, p. 07

Com esses versos do poema "Meus trinta anos" de Juan Francisco Manzano, inicia-se a edição inédita de sua autobiografia, uma das únicas a ter sido escrita por uma pessoa escravizada na América Latina. Redigido por volta de $1835 \mathrm{sob}$ a encomenda de um grupo antiescravista liderado por Domingo Miguel del Monte y Aponte, o texto de Juan Francisco Manzano é bem conhecido entre os estudiosos do escravismo, embora pouco mencionado no Brasil. Trata-se de um documento histórico fundamental por oferecer uma visão interna da escravidão no período do boom de engenhos açucareiros de mão
* gustavobicalho@gmail.com

iteratura e Literatura Comparada pelo it - UFMG.

de obra cativa em Cuba, com riqueza de detalhes. Tudo isso de um ponto de vista pouco comum, o do escravizado, e sem ocultar os horrores característicos de um sistema econômico baseado na violência da apropriação, exploração e degradação de vidas humanas e, mais especificamente, de africanos e seus descendentes. A primeira tradução desse documento no Brasil enfatiza algumas peculiaridades da autobiografia que reiteram, mas ao mesmo tempo ultrapassam, em muito, o interesse historiográfico que com razão desperta.

A maior dessas peculiaridades deriva do fato de que Manzano era um poeta. Como destaca o historiador Ricardo Salles na apresentação da edição, esse é, por si só, um fato extraordinário para alguém que tivesse nascido escravizado em qualquer parte das Américas durante o século XVIII $\mathrm{Na}$ época em que o texto foi encomendado, o contingente 
de letrados dentre os cativos não deveria chegar a $1 \%$. Ler e escrever nas sociedades escravocratas eram habilidades, em geral, restritas às elites brancas. Nas mãos dos escravizados, o livro e a pena poderiam adquirir conotações altamente subversivas e muitas vezes, como ocorreu na vida de Manzano, eram motivação para punições severas. Pode-se imaginar, então, o impacto causado por um jovem cativo ousando escrever poesia em uma realidade social sustentada por ideologias eugenistas, que negavam a existência de qualquer forma de subjetividade e talento criativo para negros e mulatos, escravizados ou não.

Ao lado de Manzano, há célebres exceções: Phillis Weathley, que, ainda na segunda metade do século XVIII, consagrou-se internacionalmente ao ter seu livro Poems on Various Subjects, Religious and Moral publicado em Londres, em 1773; Luiz Gama, o qual, pouco mais de dez anos após deixar o cativeiro e ainda antes de ganhar fama advogando com sucesso pela liberdade de centenas de escravizados, publicou suas Primeiras trovas burlescas de Getulino, em 1859. Para comprovar que era realmente autora de seus poemas, Weathley foi obrigada comparecer diante de um tribunal formado por dezoito homens brancos politicamente influentes e responder a um longo questionário. ${ }^{1}$ Já Gama, por motivos não declarados mas que podemos imaginar, não volta a ter seus poemas publicados em livros, a despeito de sua intensa atuação intelectual na imprensa e na vida política.
Como nos informa Alex Castro, tradutor e organizador da edição, Manzano também interrompeu em definitivo a publicação de seus poemas após ser preso durante a Revolta Escalera, em 1843. Mas, antes disso, deixou-nos um relato contundente de sua vida, no qual a identidade de poeta é reafirmada em diversos trechos, como uma marca de distinção pessoal. Uma história - provavelmente apócrifa, alerta Castro - sustenta que Manzano teria obtido sua liberdade após declamar o poema "Meus trinta anos" em um sarau literário, emocionando os participantes a ponto de os motivarem a pagar por sua libertação. Seja o caso verdadeiro ou não, fato é que, por meio da autobiografia, Manzano negocia sua individualidade perante a sociedade letrada cubana e transatlântica, conquistando, para além do status de escravo, a alcunha de escritor. No entanto, como a edição brasileira salienta e discute minuciosamente - e este é um de seus principais méritos -, essa negociação ocorre sob um contexto adverso às ambições literárias e pessoais do poeta. As diversas mediações, edições e rasuras a que o texto foi submetido nos anos que sucedem à escrita revelam que Manzano teve sua voz violentada em prol de interesses de grupos de homens de letras abolicionistas que, paradoxalmente, não abriam mão de práticas escravistas.

\section{EDIÇÕES E TRADUÇÕES}

Já na apresentação da obra, o escritor e pesquisador Alex Castro chama a atenção do leitor para o fato de que a narrativa,

$\begin{array}{llllll}\text { EM TESE } & \text { BELO HORIZONTE } & \text { v. } 22 & \text { N. } 3 & \text { SEF-DEZ. } 2016 & \text { BICALHO. A autobiografia do poeta-escravo [resenha] }\end{array}$


redigida de próprio punho por Manzano, foi passada a limpo e editada pelas mãos de um grupo de literatos ligados à figura de Domingo Miguel del Monte y Aponte. ${ }^{2}$ Além disso, a autobiografia só viria a ser publicada em Londres, em 1840, sob tradução do médico irlandês Richard Madden, que conhecera a narrativa por meio de del Monte durante os quatro anos que passou em Cuba, em missão pelo governo britânico. Do texto inicial de Manzano à traducão, a voz do indivíduo foi deturpada, quando não absolutamente silenciada, para favorecer a criação do personagem-escravo como testemunha autêntica que servisse aos interesses político-ideológicos do grupo delmontino e da campanha abolicionista inglesa. Como informa Castro em uma das numerosas notas explicativas da edição, trechos em que Manzano destaca sua formação letrada ou seus dotes de poeta foram "completamente cortados ou significativamente reduzidos na tradução de Madden". ${ }^{3}$ A primeira versão integral em espanhol só viria a ser publicada em Cuba no ano de 1937.

Visando aproximar-se da voz e das intenções de Manzano, Castro resgatou um dos dois manuscritos da obra encontrados na Biblioteca Nacional José Martí, em Havana. Deixando de lado um manuscrito de caligrafia refinada e sem rasuras, provavelmente redigida por Anselmo Suárez y Romero, um dos que patrocinaram a libertação de Manzano, Castro priorizou a outra versão, autógrafa. Com desvios à norma culta da língua espanhola, o manuscrito escolhido apresenta as rasuras próprias de alguém que hesita diante da escrita das agruras (inúmeras) e alegrias (raras) da própria vida, sobretudo diante da certeza de que seria lido pela mesma sociedade que o mantinha escravizado. Mesmo que a busca por um texto mais respeitoso à memória de Manzano e menos manipulado pela intencionalidade dos herdeiros das elites açucareiras não nos devolva imediatamente o texto "original", ou mais autêntico, somos contemplados com a oportunidade de ler ao avesso a história das várias manipulações sofridas pelo texto ao longo do tempo. A edição não esconde a violência sistematicamente imposta a Manzano, até mesmo quando lhe foi dada a chance de escrever com suposta liberdade sobre sua própria experiência. Um exemplo disso é o fato de que o relato é apenas a primeira metade do que o poeta-biógrafo escreveu. A segunda metade, da qual não conhecemos uma linha sequer, foi possivelmente destruída por contrariar os interesses do grupo de del Monte.

Ciente de que traduzir é um ato sempre político de refração de uma cultura em outra e buscando não repetir as injustiças do passado, o tradutor optou por apresentar ao público lusófono duas versões do texto. A primeira, uma tradução nos moldes tradicionais, prioriza a fluidez na leitura da história e um entendimento mais imediato da linguagem de Manzano. Mantiveram-se, na medida do possível, as escolhas
2. Conforme nota explicativa da edição, Domingo Miguel del Monte y Aponte era "membro Monte y Aponte era "membro ge um dos mais poderosos com mais de quarenta engenhos com mais de quarenta engenhos de açúcar e quinze mil pessoas autobiografia do poeta-escravo, p. 143). Profícuo homem de letras, editor dos primeiros jornais cubanos e promotor frequente de tertúlias literárias, se posicionava contrário à escravidão e ao tráfico negreiro, mas se opunha à abolição.

Demonstrava-se, ainda, bastante simpático às ide, ainda, bastante simpático às ideias eugenistas suposta in
africana.

3. MANZANO. A autobiografia do poeta-escravo, p. 170.

$\begin{array}{llllll}\text { EM TESE } & \text { BELO HORIZONTE } & \text { v. } 22 & \text { N. } 3 & \text { SET.-DEz. } 2016 & \text { BICALHO. A autobiografia do poeta-escravo [resenha] }\end{array}$


vocabulares do autor e a historicidade do texto, sem modernização dos termos usados à época. A paragrafação e a pontuação, muito pouco utilizadas na versão autógrafa, bem como a ortografia idiossincrática de alguém que aprendera a escrever na língua do colonizador sob condições dramaticamente adversas, foram adaptadas ao português padrão com o objetivo de tornar o texto palpável a estudantes de nível médio e à leitura não especializada. Vale ressaltar que a tradução foi favorecida pelo parentesco contextual entre o universo dos engenhos de açúcar escravistas de Cuba e sua versão igualmente exploratória, oligárquica e violenta no Brasil do século XIX.

Diante, porém, da insatisfação com a padronização da escrita de um "outro" em posição subalterna - nos termos do tradutor, uma "sanitização" do texto - fez-se necessária apresentação de uma versão, digamos, mais crua da narrativa, chamada de transcriação. Feita em parceria com o músico Pablo Zumarán, trata-se de uma tentativa de se aproximar ao máximo da voz de Manzano, da cadência de sua escrita, do ritmo de sua construção frasal, da singularidade de sua sintaxe, além de alterar o mínimo possível um léxico que ajuda a desenhar a sociedade cubana da época com um traçado análogo ao do texto-fonte. A transcriação não visa iludir o leitor com as semelhanças, no entanto. Nas palavras de Castro, o que se buscou foi a invenção de um "Manzano lusófono fictício, com os desvios da norma culta que ele teria

EM TESE
BELO HORIZONTE cometido se tivesse crescido e aprendido a escrever como uma pessoa escravizada no Brasil de princípios do século XIX" ${ }^{4}$ A instauração explicitada de um "como se" ficcional na tradução tende, paradoxalmente, a aproximar o leitor da experiência do contato direto com o documento, procedimento raro às traduções encontradas em livrarias, permitindo a um público mais amplo flertar com um tipo de leitura normalmente restrita a historiadores e à pesquisa especializada em arquivos. Vale a ressalva, no entanto, que a re-criação de uma personagem histórica subalterna sempre esbarra no risco de sua exotização, sobretudo quando se trata de buscar reproduzir uma linguagem e um comportamento desviantes da norma. No caso da obra tratada, o risco é representado pela invenção da voz de um escravo falante de um português "incorreto", com uma escrita carregada de oralidade, elementos historicamente utilizados no Brasil para estigmatizar e desvalorizar as produções discursivas e a criatividade dos afrodescendentes. Daí a importância das 341 notas que acompanham a transcriação. Compostas a partir de uma vasta bibliografia de estudos sobre Manzano, elas oferecem uma mediação importante para o leitor brasileiro, prevenindo uma visão enviesada de uma personagem tão complexa, além de servirem como ótima introdução a pesquisadores que desejem estudar o tema mais a fundo. Há, ainda, notas de natureza exegética que mereceriam ser debatidas ou mesmo contestadas por interpretações diversas.
4. MANZANO. $A$ autobiografia do poeta-escravo, p. 12 
5. MANZANO. A autobiografia do poeta-escravo, p. 33.

6. MANZANO. $A$ autobiografia do poeta-escravo, p. 165.

7. PATTERSON. Slavery and Social Death.

\section{AUTOBIOGRAFIA E TESTEMUNHO}

$O$ cuidado com a tradução e edição de um texto tão complexo favorece o contato com uma história ao mesmo tempo fascinante e assombrosa. Juan Francisco Manzano nasceu por volta de 1797 no engenho El Molino, em Matanzas, cidade conhecida como "a Atenas de Cuba", graças à prosperidade econômica e à intensa vida artística e intelectual que abrigava no início do século XIX. Filho de María del Pilar Manzano, uma das criadas de distinção da senhora Beatriz de Jústiz, Manzano foi educado de maneira distinta e isolada das demais crianças negras no engenho. Tratado, segundo Manzano, como um filho por sua senhora, a quem também "chamava de mamãe", era protegido na infância até mesmo das repreensões do próprio pai. A consciência de seus privilégios da infância, que muito o aproximavam dos meninos brancos, embora acompanhe toda a narrativa, vai sendo abandonada progressivamente à medida que o jovem Manzano é posto diante de humilhações quase diárias que o nivelam à condição de posse de outrem, desprovido de direitos e liberdades individuais diante de seus senhores. Na época da escrita da narrativa, em carta endereçada a del Monte em 15 junho de 1835, Manzano, que pede para ser considerado "um mártir", diz se saber escravo e que "o escravo é um morto perante seu senhor". ${ }^{6}$ A contradição entre um tratamento individual diferenciado, repleto de privilégios, e a consciência de sua "morte social" é a marca principal de seu relato e, embora talvez não fosse do interesse de seus editores, acaba por posicionar o texto no entrelugar da autobiografia e do testemunho.

A contradição ganha contornos estarrecedores ao entrar em cena a Marquesa de Padre Ameno, nova senhora de Manzano após a morte de Beatriz de Jústiz e principal antagonista do texto. Sob seu mando, Manzano mantém alguns de seus privilégios, mas é também muito mais repreendido e com violência desproporcional. Citemos apenas um exemplo das muitas punições injustificáveis que recebeu: Quando tinha por volta de catorze anos, o menino acompanhou a marquesa na colheita de algumas flores e plantas, como parte da distração de sua senhora. No caminho, colheu uma pequena folha de um botão de gerânio e foi despedaçando-a aos poucos pelo caminho para sentir melhor seu aroma, com a mente nos muitos versos que sempre trazia na memória. A marquesa, ao perceber o cheiro das flores despedaçadas, agarrou-o pelas mãos e quebrou-lhe o nariz. Depois, trancou-o em uma enfermaria onde permaneceu isolado com o cheiro dos cadáveres que às vezes eram depositados ali, antes de serem levados para sepultamento. Em seguida, foi mandado ao tronco. Atordoado, Manzano é incapaz de continuar descrevendo o episódio: "Oh Deus! Puxemos um vel pelo resto d'esta sena". ${ }^{8}$

Se, por um lado, cenas como essa nos horrorizam, sobretudo ao pensarmos que Manzano era um privilegiado
MANZANO A autobiografia do poeta-escravo, p. 117

$\begin{array}{llllll}\text { EM TESE } & \text { BELO HORIZONTE } & \text { v. } 22 & \text { N. } 3 & \text { SET.-DEz. } 2016 & \text { BICALHO. A autobiografia do poeta-escravo [resenha] }\end{array}$


9. MANZANO. $A$ autobiografia do poeta-escravo, p. 116.

10. LIENHARD. “El esclavo es un ser muerto ante su señor", p. 118. quando comparado aos demais escravizados, por outro, somos convidados a refletir que a relação com a marquesa é bem mais complexa que a frieza sugerida por tal punição. O enorme apego e a irresistível atração que esta sentia pelo menino - "eu era o cachorrinho de minha sinhá", diz Manzano9 - impedia que seus castigos fossem maiores e abriam espaço para a negociação de algumas vantagens. Expressa pelo caráter altamente elíptico e sugestivo da narrativa, a construção textual da narração faz com que Castro e estudiosos como Martín Lienhard sugiram que, no lugar de uma possível "afinidade eletiva" entre as duas personagens, a perversa relação senhora-escravo faz brotar "um drama não isento de aspectos sadomasoquistas". ${ }^{10} \mathrm{O}$ fato de que a Marquesa de Prado Ameno ainda estava viva na época de sua redação e de que um de seus filhos era membro do grupo de del Monte talvez ajude a explicar o caráter controverso e lacunar das descrições dessa personagem, muitas vezes elogiada no texto e poupada da responsabilização pelos atos de tortura infligidos contra seu subordinado. Como estratégia narrativa, o poeta-biógrafo parece ter cifrado os ataques mais agudos à sua senhora como forma de defender-se de prováveis retaliações.

A leitura d'A autobiografia do poeta-escravo é, portanto bastante elucidativa da complexidade da textualização de relações sociais em um sistema de dominação e sujeição.
Se Juan Francisco Manzano representa uma pequena elite dentre os demais escravos, o registro de sua vida expõe a generalização da crueldade característica ao regime escravocrata, até mesmo para aqueles que tinham a chance de frequentar os salões, jantares, tertúlias literárias e mesmo as dependências íntimas do mundo dos brancos. Nesse contexto, a fruição estética, frustrada e repreendida em episódios como o do gerânio triturado, é reconquistada pelo poeta na escrita de sua narrativa autobiográfica, em que a encontramos entrelaçada em uma retórica denunciativa. Valorizando tanto a construção autobiográfica do poeta quanto a verve testemunhal do escravizado, a publicação da edição em português oferece ao público lusófono a oportunidade única de testemunhar o nascimento de uma forma muito peculiar da escrita de uma vida nos limites de uma página profundamente melancólica da história do Ocidente.

\section{REFERÊNCIAS}

GATES JR., Henry Louis. The Trials of Phillys Weathley. Nova York: Basic Civitas Books, 2003.

IENHARD, Martín. El esclavo es un ser muerto ante su señorAutobiografía del esclavo Juan Francisco Manzano (Cuba 1835). In: LIENHARD, Martín. Disidentes, rebeldes, insurgentes:

Resistencia indígena y negra en América Latina - Ensayos de

historia testimonial. Madrid: Iberoamericana; Frankfurt: Vervuet 2007. p. $113-125$ 
MANZANO, Juan Francisco. A autobiografia do poeta-escravo.

Organização e tradução de Alex Castro. São Paulo: Hedra, 2015.

PATTERSON, Orlando. Slavery and Social Death. Cambridge;

Massachusetts; Londres: Harvard University Press, 1982. 